\title{
Correction to: A Review of Biological Monitoring of Aquatic Ecosystems Approaches: with Special Reference to Macroinvertebrates and Pesticide Pollution
}

\section{R. G. I. Sumudumali ${ }^{1}$ - J. M. C. K. Jayawardana ${ }^{2}$ - S. Malavipathirana ${ }^{3}$ - E. P. N. Udayakumara ${ }^{2}$ S. K. Gunatilake ${ }^{2}$}

Published online: 27 March 2021

(c) Springer Science+Business Media, LLC, part of Springer Nature 2021

Correction to: Environmental Management https://doi.org/10.1007/s00267-020-01423-0

In the original publication, the authors "S Malavipathirana, EPN Udayakumara, SK Gunatilake" were not included in the author group. The correct list of authors and correct Acknowledgements are published with this correction.
Acknowledgements The authors would like to acknowledge the Accelerating Higher Education Expansion and Development (AHEAD) World Bank funded the Sri Lankan government project (AHEAD/DOR/STEM/33) for funding this work.

The original article can be found online at https://doi.org/10.1007/ s00267-020-01423-0.

$\triangle$ J. M. C. K. Jayawardana jayawardanack@yahoo.com

1 Faculty of Graduate Studies, Sabaragamuwa University of Sri Lanka, Belihuloya, Sri Lanka

2 Department of Natural Resources, Faculty of Applied Sciences, Sabaragamuwa University of Sri Lanka, Belihuloya, Sri Lanka

3 Department of Physical Sciences and Technology, Faculty of Applied Sciences, Sabaragamuwa University of Sri Lanka, Belihuloya, Sri Lanka 